\title{
Brand awareness as predictors of repurchase intention: Brand attitude as a moderator
}

\author{
Nurlaely Razak \\ School of Economics Makassar (STIEM Bongaya) Indonesia \\ Orfyanny Syahreffy Themba \\ School of Economics Makassar (STIEM Bongaya) Indonesia \\ Herman Sjahruddin \\ School of Economics Makassar (STIEM Bongaya) Indonesia
}

\begin{abstract}
This study empirically investigates the moderating effect of brand attitude on the relationship between brand awareness and repurchases intention. The study proposes that the brand attitude acts as a quasi-moderator of the relationship between brand awareness and repurchase intention. The results support the predictions of the study. The results indicate that brand attitude moderates the relationship between brand awareness and repurchase intention such that when brand attitude is high, the relationship between brand awareness and repurchase intention is positive, and vice versa, when the brand attitude is low, the relationship between brand awareness and repurchase intention is negative. Furthermore, the results reveal that brand awareness and brand attitude has a positive relationship to repurchase intention. In other exploration results, found consumer-specific characteristics affect brand awareness. Consumer characteristics (e.g., ages, gender, and frequency of consumption (in times per month)) are not significantly and positively related to brand awareness, furthermore consumer characteristics is significantly and positively related to brand attitude

Keywords: brand awareness, brand attitude, repurchase intention, consumer characteristics
\end{abstract}

\section{INTRODUCTION}

From this time the dependence of modern people living in the city at fast food is very high, this is due to their busy work place besides the support of delivery services prepared by the fast food industry and the high level of consumer confidence in fast food that has worldwide (e.g. McDonalds and Kentucky fried chicken Fast Food) is very high, making it easier for consumers to make repeat purchases. The intention of consumers to buy again has two aspects, namely the desire to buy (re-purchase) and the desire to provide recommendations (referrals). Repurchase intention occurs after consumers consume a product or service preceded by a process of evaluating products and services (Cronin \& Taylor, 1992; Fitzgibbon \& White, 2005). The experience gained by consumers from consuming goods or services into memory, feelings of satisfaction or dissatisfaction will always be remembered by consumers, if the consumers feel satisfied then the intention that arises in the consumer will be higher (Bahar, A., \& Sjaharuddin, H., 2017).

Competition between McDonalds and Kentucky fried chicken (KFC) in seizing the fast food consumer market in Indonesia, one of which can be seen based on the number of outlets they have. Until June 2018, KFC has 632 outlets with revenues of 2,996.99 (in billion rupiah) while McDonalds, up to February 2018 only has 181 outlets throughout Indonesia with total revenues up to the first semester of 2018 of 2.97 trillion rupiah. Important efforts that marketers can make to increase consumer awareness of their brand as a mechanism to expand 
the brand market. Brand awareness is the ability of someone who is a potential buyer to recognize or recall a brand that is part of a product (Aaker, 1991).

A brand consists of a name, term, sign, or symbol, or a combination of them, that attempts to represent the unique benefits a company can provide to consumers through a particular product or service, in terms of attributes, value, and culture (Kotler, 1997). As pointed out by Keller (2008), the important role played by consumers is to identify products from those of competitors. Indeed, consumers are facing an increasingly varied range of products on the market, while they know more about their products than consumers. This is the uncertainty in consumers' minds when they make a purchase. In such cases, brands can serve as symbols for product positioning (Erdem \& Swait, 2004; Themba, OS et al., 2019). Managers of global brands must evaluate the performance of their marketing strategies in different markets. This is an important step, because the systematic monitoring and follow-up of brand performance separates high-performing brands from their low performance counterparts (Romaniuk et al., 2017). Brand awareness can help link brands with associations expected by companies, create consumer familiarity with brands, and show commitment to their customers. The level of brand awareness ranges from the level of recognize the brand that consumers can get to know a brand, to the extent that the brand becomes dominant brand recalled, the brand is the only one that is remembered and becomes the identity of the product category. High brand awareness can cause consumers to have confidence in the interest in repurchasing made. This can reduce the perceived risk level of the brand to be purchased (Mohseni et al., 2018).

Brand awareness also acts as a critical factor in the consumer purchase intention, and will accumulate in consumers' mind to consumer purchase decision influence. A product with a high level of brand awareness will receive higher consumer preferences because it has higher market share and quality evaluation (Dodds et al., 1991). Brand awareness plays an important role in consumer buying interest because consumers tend to make purchases on better-known products (Mac Donald \& Sharp, 2000). Brand awareness can help consumers to know the brand of the product and make purchasing decisions (Percy \& Rossiter, 1992). Brand awareness has a large influence in elections and can be considered before choosing a product (Hoyer \& Brown, 1990). Products with high brand awareness will receive higher choices from consumers because they have a higher market share and quality evaluation (Dodds et al., 1991; Grewal et al., 1998).

The importance of brand awareness in consumer decision making has three main reasons, first, so that consumers think of a brand when making purchasing decisions in the brand product category. Increasing brand awareness increases the likelihood that a brand will be part of a set of considerations, representing a basket of brands, which are considered when making a decision purchase. Second, brand awareness can influence brand decisions in a set of considerations, even if there are basically no other associations with the brand. In situations of low involvement, it has been shown that just basic brand awareness may be enough to influence brand choice. Third, brand awareness influences the formation and strength of brand associations that shape brand image (Keller, 1993).

Consumers tend to choose brands with high familiar brand awareness when making decisions. Brand awareness is a tool that simplifies purchase decisions. They infer the quality of a product based on its brand awareness and have a more intention-to-purchase familiar brand for their unfamiliar brands (Ho, CH et al., 2015). Other scholars' views explain that a brand with high awareness and good image can promote brand loyalty to consumers, and the higher brand awareness, the higher brand trust and purchase intention are to consumers (Aaker \& Keller, 1990; Ramli \& Sjahruddin, 2015 ) The brand awareness increases the likelihood to consider 
the brand when making a purchase decision (Chakravarti \& Janiszewski, 2003). Brand awareness has a positive effect on purchase intentions (Chi, HK, et al., 2009; Hutter, K., 2013; Gunawan, FA, \& Dharmayanti, 2014; Ho, CH et al., 2015; So \& Simamora, 2015 ; Jung \& Seock, 2016; Jamil, K. et al., 2017; Jamali \& Khan, 2018; Pandjaitan, 2018; Nugraha \& Setyanto, 2018). The debate raised other scholars that, the brand awareness has significant impact on the purchase intention (Wu \& Ho, 2014). This research tried to call on previous research recommendations, that the analytical consumers were more likely to blame the brand after being exposed to negative brand information (Monga \& John, 2008). Further, a number of recent studies have found the influence of negative publicity has on consumer attitudes and behavior is moderated by the strength of the brand-consumer relationship (Ullrich \& Brunner, 2015; Um \& Kim, 2016). Current literature shows that the functionality of a consumer product only when the consumers consider deciding to purchase a good. Research indicates that symbolic qualities associated with consumer brands are frequently the principal motivators behind consumer purchase decisions. According to the standard attitude change model proposed by American psychologist (Hovland, 1959), external stimuli can affect the change of people's attitude.

According to the proposed theory and plan of rational behavior and planning by American Scholar Fishbein \& Ajzen (1975), it can be seen that individual attitudes affect them. Brand attitudes enhance purchase intentions among consumers as their motivation gets increased (Mackenzie \& Spreng, 1992). The better the attitude towards the brand that is shown by consumers, the higher the level of consumers in purchasing intention (Jung \& Seock, 2016; Sallam, MA, \& Algammash, FA, 2016; Lee, E. B et al., 2017; Parks, JC , 2018; Yu, M. et al., 2018; de Villiers et al., 2018; Singh \& Banerjee, 2018; Fitri, FR, 2018). The greater organizational responsibility will lead to more extreme emotions towards the organization followed by more extreme repurchase intentions with the direction of those who are dependent on customers' positive or negative experiences (Shank \& Robinson, 2019).

\section{LITERATURE REVIEW}

\section{Repurchase intention}

The intention is an attitude statement about how someone will behave in the future (Söderlund \& Öhman, 2003). The interest in repurchase intention is a consumer commitment that is formed after the consumer purchases a product or service. This commitment arises because the consumer's positive impression of a brand and consumers feel satisfied with the purchase (Hicks et al., 2005). The interest of consumers to repurchase is one measure of the success of a company, especially service companies (Butcher, 2005). The interest in repurchasing is the consumer's decision to repurchase a product or service based on what has been obtained from the same company, to make expenditures to obtain these goods and services and there is a tendency to be done regularly (Hellier et al., 2003).

The accumulation of consumer experience and knowledge of a brand is a factor that can influence consumers to repurchase the same brand. Brand equity not only provides direct benefits, but also long-term benefits by maintaining consumers to keep repurchasing their products (Aaker, 1992). A strong brand will cause consumers to always remember the brand. With the experience that consumers get from a product with a particular brand will create a positive impression on the product and consumers will make repeat purchases (Hellier et al, 2003; Bahar, A., \& Sjaharuddin, H., 2017). There are four indicators to measure repurchase interest (Ferdinand, 2002), namely: (1) transactional interest which is a person's tendency to buy products, (2) explorative interest is the behavior of someone who is always looking for information about the product he is interested in and seeking information to support positive characteristics of the product, (3) preferential interest is an interest that describes the 
behavior of a person who has a primary preference for the product, this preference can change if something happens with his preferred product, (4) referential interest namely the tendency of someone to refer products to other people.

\section{Brand Awareness}

The initial stage needed to build a brand is how producers build Brand Awareness through information in memory in the first place. Brand awareness is important before brand association can be formed. When consumers have little time to consume, proximity to brand names will be sufficient to determine purchases (Pitta \& Katsanis, 1995). The concept of brand awareness is the ability of buyers to identify (recognize or remember) a brand that is sufficiently detailed to make a purchase. Brand awareness is the first step for every consumer of each new product or brand offered through advertising (Rossiter \& Percy, 1997). Brand awareness is a given brand that belongs to a particular category of products (Romaniuk, Wight, \& Faulkner, 2017). Advertising creates awareness of a new brand, and awareness itself will produce a desire to buy, then after that a brand will get its way to achieve the desired goal (Aaker, 1995). Brand awareness is defined in terms of the ability that consumers have to associate a brand with its product category (Aaker, 1991). This refers to the strength of the existence of a brand in the consumer's mind. Awareness presents the lowest level of brand knowledge. Brand awareness involves a process starting from feeling unfamiliar with the brand to being sure that the brand is the only one in a certain class of product or service. In this case if a brand has been able to seize a place that remains in the minds of consumers it will be difficult for the brand to be shifted by other brands, so that even though consumers are filled with different marketing messages every day, consumers will always remember the brand has been known before (Aaker, 1996).

Brand awareness is a general purpose communication for all promotional strategies. By creating brand awareness, marketers hope that whenever the category needs arise, the brand will be brought back from memory which is then taken into consideration by various alternatives in decision making. Brand awareness level can be measured by asking consumers to mention which brand name is considered by consumers. Whether recollection or brand awareness has begun to be adequate depends on where and when a purchase decision is made. The right brand awareness strategy depends on how well-known the brand is. Sometimes the purpose of promotion is to maintain a high level of brand awareness (Peter \& Olson, 2000). Brand awareness has a number of levels from the lowest level (unaware of the brand) to the highest level, at the lowest level there are: (1) Unaware brands (unaware of the brand) are the lowest level in brand awareness pyramids where consumers are unaware the existence of a brand, (2) Brand Recognition (brand recognition) is a minimum level of brand awareness, where the introduction of a brand appears again after the recall is done through aided recall, (3) Brand Recall (recall of the brand) is a recall unaided recall, and (4) Top of Mind (the top of mind) is the brand that was first mentioned by consumers or that first appeared in the minds of consumers, or the brand is the main brand of various brands that exist in the mind of a person consumer. There are three indicators that are used to measure brand awareness, namely: (1) embedded in the minds of consumers about the brand of a product, (2) the brand is easy to remember, and (3) the brand is easily recognized by type (Peter \& Olson, 2000).

\section{Brand attitude}

Attitude can be defined as the evaluation of overall concept done by a person; the attitude is as an individual faced with a stimulus that calls for individual reactions (Peter, J.P. et al., 1999). The attitude of consumers is the second element of the elements will form an impression of the brand. Consumers' attitudes toward brands can be interpreted as delivering what is expected by buyers to satisfy the needs of buyers. Therefore, consumer attitudes can spur the desire or 
intention to buy a product. A brand attitude is the overall evaluation of consumers towards the brand, in the brand equity model it was found that an increase in market share occurred when the attitude towards brand is more positive. Attitudes toward certain brands often influence whether consumers will buy or not (Chaudhuri, 1999).

The attitude towards the brand is defined as the overall evaluation of the brand carried out by consumers and reflects the consumer response to the brand. Attitudes toward brands can be formed from beliefs about the intrinsic attributes of a brand and also the functional benefits and accompanying experience (Keller, 1998). The attitude towards the brand can also be challenged through one's basic beliefs about the extrinsic attributes of a brand and also the symbiotic benefits that are in it (Keller, 1998). The attitude towards the brand (attitude toward to the brand) is consumer behavior that is closely related to brand value for consumers and consumer expectations (Percy \& Rossiter, 1992). The attitude towards the brand is considered positive depending on the brand is preferred, the brand is more remembered (Shapiro \& Krishnan, 2001; Till \& Baack, 2005).

Loudon \& Della Bitta (1993) explain that attitudes can be formed through three factors, namely: (1) Personal Experience, (2) Group associations, (3) Influential others. Personal experience (Personal experience) will shape and influence appreciation of social stimulus. The response will guarantee one of the foundations of attitude. The requirement to have a response and appreciation is to have experience related to the object of psychology. There are three indicators that are used to measure brand attitude, namely: (1) attitude of interest, (2) attitude of trust, and (3) positive impression (Chaundhuri, 1999).

\section{Data Collection and sample}

\section{METHODS}

Data Quantitative ties through the executive register are used in analyzing this study. Respondents used are those who have consumed fast food more than once and are routine every month at McDonalds and Kentucky fried chicken. Observations were made in October November 2018 so that a sample of 245 customers was obtained with a return rate of $100 \%$. There were 108 customers who did not provide complete answers so that only 137 questionnaires could be used for analysis. About $62 \%$ of respondents are women and most are in the age group 29-34 years 38\% with the level consumption of frequency $>6$ times per month.

\section{Measures}

This study was conducted by a quantitative research design, using a questionnaire containing a number of questions or items adapted from used in previous related studies. The items used to measure repurchase interest (Ferdinand, 2002), brand awareness (Peter \& Olson, 2000), and brand attitude (Chaudhuri, 1999). Question-statements were answered on a 5-point Likert scale, with 1 referring to strongly disagree and 5 referring to strongly agree. The data collection prior to administration of the survey in order to establish the validity and reliability is adapted and developed items.

\section{RESULTS}

To analyze causal relationships between constructs used in the study, the structural equation modeling (SEM) approach was adopted. The technique can be divided into two parts. The measurement model which relates to measured indicators to latent variables. The structural model is the part that relates latent variables among one another. The estimation of the model requires a measurement model and a structural model using appropriate estimation methods. Analysis of the model was done using the Partial Least Square (PLS) software, Warp PLS 6.0. 
Warp PLS 6.0 includes the fit indices model, the 'p' values for path coefficient and the latent variable coefficients to assess reliability and validity considerations. Warp PLS 6.0 evaluates both measurement models as well as structural models simultaneously.

The PLS regression algorithm with bootstrapping method of sampling was used for estimating the model that maximizes the variance explained in the latent variable scores by the latent variable indicators. Estimates include path coefficients with 'p' values, indicators' weights, loadings, and factor scores. The validity and reliability criteria vary depending on the nature of the construct. For evaluation of measurement indicators, the loading of indicators should be more than 0.5 and the corresponding ' $\mathrm{p}$ ' should be less than 0.01 , after estimation. The causal assumptions were verified only on the basis of a valid model. The pre-processing of the Warp PLS data part of 6.0 analyses confirmed the data for further analysis with regard to missing values, zero variance (Kock, 2015; Hasanuddin \& Sjahruddin, 2017).

All the factor loadings of the reflective indicators were found to be more than 0.5 with $\mathrm{p}=<0.01$.

Table-1 Factor loadings and cross-loadings

\begin{tabular}{lccccccc}
\hline Constructs & BAss & BA & RP & Char & BA*BAss & SE & P value \\
\hline BAS1 & $(.860)$ & .143 & -.032 & .014 & .104 & .070 & $<.01$ \\
BAS2 & $(.796)$ & -.004 & -.070 & -.068 & -.079 & .071 & $<.01$ \\
BAS3 & $. .882)$ & -.136 & .094 & .048 & -.030 & .070 & $<.01$ \\
BAT1 & -.079 & $(.872)$ & .044 & .163 & -.019 & .070 & $<.01$ \\
BAT2 & -.040 & $(.871)$ & -.016 & -.118 & -.079 & .070 & $<.01$ \\
BAT3 & .135 & $. .766)$ & -.031 & -.052 & .112 & .072 & $<.01$ \\
RPI1 & .036 & -.220 & $(.755)$ & .114 & .048 & .072 & $<.01$ \\
RPI2 & -.080 & -.026 & $. .592)$ & .004 & -.111 & .074 & $<.01$ \\
RPI3 & .160 & .078 & $. .669)$ & -.129 & -.024 & .073 & $<.01$ \\
RPI4 & -.146 & .218 & $. .593)$ & -.003 & .077 & .074 & $<.01$ \\
Age & -.032 & .224 & -.104 & $.835)$ & .014 & .070 & $<.01$ \\
Buy & -.041 & -.273 & .181 & $. .799)$ & -.135 & .071 & $<.01$ \\
Gdr & .175 & .091 & -.173 & $(.537)$ & .285 & .079 & $<.01$ \\
BAT1*BA & .176 & -.186 & .067 & .024 & $(.763)$ & .072 & $<.01$ \\
BAT1*BA & -.235 & .150 & .164 & -.042 & $(.842)$ & .070 & $<.01$ \\
BAT1*BA & -.062 & .112 & -.136 & -.093 & $(.819)$ & .071 & $<.01$ \\
BAT2*BA & .213 & -.303 & -.135 & .122 & $(.682)$ & .073 & $<.01$ \\
BAT2*BA & -.222 & .142 & .033 & -.012 & $(.800)$ & .071 & $<.01$ \\
BAT2*BA & -.013 & .097 & -.348 & -.038 & $(.766)$ & .072 & $<.01$ \\
BAT3*BA & .380 & -.379 & .215 & .145 & -.549 & .075 & $<.01$ \\
BAT3*BA & -.173 & .147 & .237 & -.027 & -.714 & .072 & $<.01$ \\
BAT3*BA & .109 & .068 & -.050 & -.016 & -.660 & .073 & $<.01$ \\
\hline
\end{tabular}

We estimated model with path coefficients and corresponding p-values are illustrated in Figure 1. 


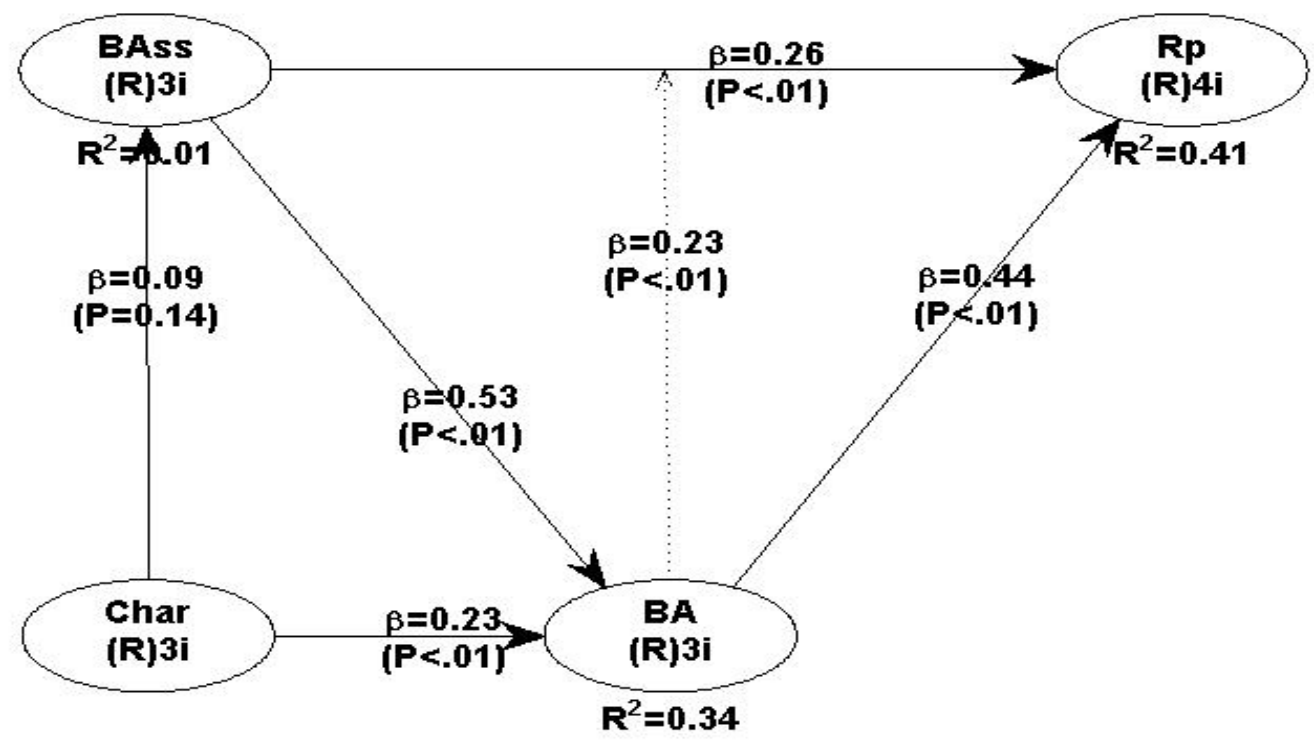

Figure 1. Estimated Model with moderation paths

Table-2 Composite reliabilities (CR)

\begin{tabular}{ccccc}
\hline BAss & BA & RP & Char & BA*BAss \\
.884 & .876 & .849 & .814 & .914 \\
\hline
\end{tabular}

The composite reliability, Cronbach alpha and average variance extracted (AVE) were above the threshold limits. The composite reliability coefficients ranged from .814 to .914 .

Table-3 Correlations among variables with square roots of AVE on the diagonal

\begin{tabular}{lccccc}
\hline \multicolumn{1}{c}{ Constructs } & BAss & BA & RP & Char & BA*BAss \\
\hline BAss & $(.847)$ & .506 & .378 & .049 & -.323 \\
BA & .506 & $(.838)$ & .365 & .233 & -.123 \\
RP & .378 & .365 & $(.656)$ & -.105 & .007 \\
Char & .049 & .233 & -.105 & $(.695)$ & -.031 \\
BA*BAss & -.323 & -.123 & .007 & -.031 & $(.738)$ \\
\hline
\end{tabular}

The square root of AVE for all constructs was found to be more than any of the correlations involving that latent variable. All these observations confirmed the reliability and validity of the constructs making it suitable to draw conclusions on causality

Table-4 Model fit and quality indices

\begin{tabular}{ll}
\hline \multicolumn{1}{c}{ quality indices } & Value \\
\hline Average path coefficient (APC) $=.296$ & $\mathrm{P}<.01$ \\
Average R-squared (ARS) $=.254$ & $\mathrm{P}<.01$ \\
Average adjusted R-squared (AARS) $=.244$ & $\mathrm{P}<.01$ \\
\hline
\end{tabular}

The validity of the model was evaluated with various fit indices. It was recommended that the ' $p$ ' values for both the average path coefficient (APC) and the average R-squared (ARS) be lower than 0.05. In addition, it was recommended that the average variance inflation factor (AVIF) be lower than 5 (Kock, 2010).It was found that all three fit criteria were met and the model had an acceptable predictive and the model well represented explanatory quality as the data. 
Razak, N., Themba, O. S., \& Sjahruddin, H. (2019). Brand awareness as predictors of repurchase intention: Brand attitude as a moderator. Advances

Table-5 Latent variable coefficients

\begin{tabular}{lccccc}
\hline \multicolumn{1}{c}{ Measures } & BAss & BA & RP & Char & BA*BAss \\
\hline R-squared & .008 & .339 & .415 & & \\
Adj. R-squared coefficients & .001 & .329 & .401 & & \\
Cronbach's alpha & .802 & .886 & .552 & .824 & .893 \\
Av. Var. extracted & .717 & .702 & .430 & .483 & .545 \\
Full collinearity VIFs & 1.599 & 1.532 & 1.298 & 1.108 & 1.141 \\
Q-squared & .009 & .340 & .402 & & \\
\hline
\end{tabular}

The Cronbach's alpha coefficients ranged from .802 to .893. Therefore, it can be concluded that the measurement model presents acceptable reliability. The model emerged as one with satisfactory value for R-squared and Q-squared being indicators for predictive validity.

Table-6 effect sizes for Path coefficients

\begin{tabular}{lccccc}
\hline \multicolumn{1}{c}{ Measures } & BAss & BA & RP & Char & BA*BAss \\
\hline BAss & - & - & - & .008 & - \\
BA & .283 & - & - & .056 & - \\
RP & .111 & .248 & - & - & .055 \\
\hline
\end{tabular}

The effect sizes for Path coefficients ranged from .055 to .283.

Table-7 Total effects

\begin{tabular}{lccccc}
\hline \multicolumn{1}{c}{ Measures } & BAss & BA & RP & Char & BA*BAss \\
\hline BAss & & & & .090 & \\
BA & .528 & & .275 & \\
RP & .498 & .443 & & .146 & .226 \\
\hline
\end{tabular}

The total effect a ranged from .090 to .528 .

Table-8 Path coefficients and $P$ values

\begin{tabular}{lccccc}
\hline \multicolumn{1}{c}{ Measures } & BAss & BA & RP & Char & BA*BAss \\
\hline BAss & - & - & - & $\beta=.009, p=>.14$ & - \\
BA & $\beta=.528, p=<.01$ & - & - & $\beta=.228, p=<.03$ & - \\
RP & $\beta=.264, p=<.01$ & $\beta=.443, p=<.01$ & - & - & $\beta=.226, p=<.03$ \\
\hline
\end{tabular}

In this paper, we examine the contextual factors of consumer-specific characteristics that affect brand awareness. Consumer characteristics (e.g., ages, gender, Frequency of consumption (in times per month)) are not significantly and positively related to brand awareness (Hypothesis $1, \beta=.009, p=>$.14). These results are different from East's (1997) that the brand awareness is a brand and its differentiation from other brands in the field. Brand recognition is how much the buyer will know about the product features or features compared to other similar products. Brand recognition here is the introduction of physical brand attributes such as color, size and shape, so packaging and design are very important. Color, size and shape, so packaging and design are very important (Howard, 1994). Brand awareness can help link brands with associations expected by companies, create consumer familiarity with brands, and show commitment to their customers. The level of brand awareness ranges from the level of recognize the brand that consumers can get to know a brand, to the extent that the brand becomes dominant brand recalled, the brand is the only one that is remembered and becomes the identity of the product category. The recognition of the brand in this study was not due to the Consumer characteristics indicated by (e.g., ages, gender, and frequency of consumption (in times per month)). 
Consumer characteristics (e.g., ages, gender, and frequency of consumption (in times per month)) are significantly and positively related to brand attitude (Hypothesis 2, $\beta=.228, p=$ $<.03)$. The evidence supports Chaudhuri (2000) that brand attitude is the overall evaluation of consumers on brands, in the brand equity model it was found that an increase in market share occurs when consumer attitudes toward brands are positive. Brand attitudes, the most abstract component of brand associations is defined as the overall evaluation of brands carried out by consumers (Keller, 1998) and reflects consumer responses to the brand. Brand attitudes can be formed from beliefs about the intrinsic attributes of a brand and also the functional benefits and accompanying experience (Zeithaml, 1988; Keller, 1993). Consumers are able to conduct continuous evaluations due to several factors, (i.e. gender) that women are more selective in choosing food or drink to consume compared to men. Ages factor, consumers who are in the age group 29-34 years tend to have a relatively not busy work time so that they have the opportunity to choose a brand, then they give a positive assessment of the brand they choose. Brand attitude is said to be positive if the consumer's ability to recall or recognize a brand is high, then a good response or attitude will be shown by consumers towards the brand. The response will guarantee one of the foundations of attitude. The requirement to have a response and appreciation is to have experience related to the object of psychology.

Brand awareness is significantly and positively related to brand attitude (Hypothesis $3, \beta=$ $.528, p=<.01$ ). These results explain that consumers' high ability to recall or recognize a brand results in better consumer responses or attitudes towards the brand. This condition is caused because the McDonalds and Kentucky fried chicken has been embedded in the minds of consumers, the aroma and taste, which has an impact on the attitude of consumers who are increasingly interested and trusting which ultimately gives a positive impression. Consumers may rely on existing attitudes towards brand awareness when forming a brand or brand that can be changed over the time. Attitudes towards the brand can be considered as consumers' general liking or lack thereof. Brand awareness helps develop strategic positions to provide goodwill from consumers and stakeholders. Brand awareness defined by Keller (2003) as a personal meaning about a brand stored in consumer memory, that is, all descriptive and evaluative brand-related information, which relates to the cognitive illustration of a brand. It relates to the likelihood of being branded with ease and which it does so. Brand awareness consists of brand familiarity and brand recognition (Keller, 1993).

Consumers' awareness towards the company or brand can be as one of the stepping stones in the customer purchasing process. The higher degree of awareness can improve the possibility of purchasing products or services. It can provide the company with a standing of sustainable competitive advantage. Consumers' awareness is the instrument whereby businesses use to impact on consumer attitudes to brand or company by creating a target audience towards a particular organization, or product. In order to identify the success of consumer attitude to brand or company, it is important to create a favorable brand association and brand belief. While defining brand awareness can be defined as customer's capability to distinguish and recognize brand in diverse contexts. Awareness can affect perceptions and attitudes. Brand awareness reflects the salience of the brand in the customers' mind (Foroudi, 2019).

Brand awareness is positively related to repurchase intention (Hypothesis 4, $\beta=.264, p=$ $<.01)$. These results explain that high brand awareness results in high consumer willingness to repurchase intention. Consumers will tend to buy products with brands that are well-known brands compared to products whose brands are still unfamiliar to their ears. The evidence supports the statement of Percy \& Rossiter (1992); brand awareness helps consumers to recognize the brand in the product category and influences them to make purchase decisions. Study of Hoyer \& Brown (1990) showed the impact of brand awareness on choice, frequency 
and brand sampling, which shows that consumers are aware of the brand awareness, has positive impact on consumer brand choice leading toward purchase intention. Without the support of brand awareness, no other communication effects emerge. For a consumer who buys a product of a brand, first of all, they must be made to know the brand. Attitudes towards brands cannot be formed, and interest in buying will not arise unless brand awareness already exists in their minds. (Percy \& Donovan, 1991).

Brand attitude is positively related to repurchase intention (Hypothesis 5, $\beta=.443, p=<.01$ ). A rational consumer will choose products of good quality, affordable or cheaper prices and products that are easily obtained. The quality of products desired by consumers concerns the benefits for fulfilling their needs and safety for consumers, so consumers feel comfortable in using these products. Attitudes toward brands form the basis of actions and actions taken by consumers regarding certain brands. Consumer action is a function of trust, and from that belief it can be predicted that the actual attitude of a person is more interested in a brand, the stronger the person's desire to own and choose the brand (Fishbein \& Ajzen, 1975). The attitude towards the brand represents the influence of consumers on a brand, which can lead to real action, such as the choice of a brand, the higher the consumer's interest in a brand, the stronger the person's desire to own and choose the brand (Keller, 1998). The findings of this study confirm that McDonalds and Kentucky fast food fried chicken is a brand that is able to provide satisfaction so that the potential of fast food in meeting the reasons for consumers' desire to buy McDonalds and Kentucky fried chicken will definitely increase. With repeated purchases of fast food the consumer then shows the process of buying interest re-routine, which in the later stages of the purchase will be structured, thus accelerating the decisionmaking process to make repeat purchases.

The brand attitude has a moderate effect on brand awareness towards repurchase intention (Hypothesis 6, $\beta=.226, p=<.03$ ). In order to test the moderating effects, interaction between the independent variable (brand awareness) and the moderator (brand attitude). The interaction between the independent variables and the moderator if the interaction term significantly contributes to the variance of the dependent variables after controlling the main effects. In conclusion, we argue that brand attitude is a quasi-moderator because we posit that it not only interacts with the predictor of the variable brand awareness, but also acts as a predictor of repurchase intention. Shimp (2010) demonstrates that attitudes toward a brand of personal preference and are convinced to be a determinant of customers' behavior toward a brand as well, consumer attitude toward a brand, also refers to brand attitude, is an important component of the value of brand's equity. Bridge between customers' background characteristics and consumption to fulfill their psychological needs can be described as brand attitudes (Kotler, \& Armstrong, 2000). This study explains that attitudes are interested, the attitude of trust and positive impression proven to strengthen the relationship between brand awareness towards repurchase intention.

\section{CONCLUSIONS}

To Briefly reiterate, this study found that controlling for several factors, consumer characteristics (e.g., ages, gender, and frequency of consumption (in times per month)) is not significantly and positively related to brand awareness, but Consumer characteristics (e.g., ages, gender, and Frequency of consumption (in times per month)) are significantly and positively related to brand attitude. Brand awareness is significantly and positively related to brand attitude. Furthermore Brand awareness and brand attitude is significantly and positively related to repurchase intention. Therefore, marketing managers should make sure their brand awareness measures are relevant to the current brand status, that is, and not a reflection of their own personal preference, the same thing should be done also on the brand attitude. 
Furthermore this study confirmed the moderating role brand attitude on repurchase intention gained; we found support for the moderating role in regards to repurchase intention. This research, as is the case with all research, has some limitations. One such limitation science to generalizability since this research was executed in the context of one area, generalizing to others is not suggested, rather than retesting in additional contexts is recommended. Another limitation is that this is an investigated knowledge sharing and gaining study in a holistic manner. For example, the practitioners should understand that they can improve the intention even if the brand attitude is not supportive of them simply beginning to brand awareness. However, they should also keep synergistic relationships between the two. Hence improving the brand attitude will amplify the effects of brand awareness.

\section{References}

Aaker DA. (1991). Managing Brand Equity. New York: The Free Press.

Aaker, DA (1992). The value of brand equity. Journal of business strategy, 13 (4), 27-32. https://doi.org/10.1108/eb039503

Aaker, DA (1995). Strategic Market Management, John Willey \& Sons. Inc,

Aaker, DA (1996). Measuring brand equity across products and markets. California management review, 38 (3).

Aaker, DA, \& Keller, KL (1990). Consumer evaluations of brand extensions. Journal of marketing, 54 (1), 27-41. https://doi.org/10.1177\%2F002224299005400102

Bahar, A., \& Sjaharuddin, H. (2017). Effect of Product Quality and Service Quality on Customer Satisfaction and Repurchase Intention.

Butcher, K. (2005). Differential impact of social influence in the hospitality encounter. International Journal of contemporary hospitality management, 17 (2), 125-135. https://doi.org/10.1108/09596110510582323

Chakravarti, A., \& Janiszewski, C. (2003). The influence of macro-level motives on consideration of composition sets in novel purchase situations. Journal of Consumer Research, 30 (2), 244-258.

https://doi.org/10.1086/376803

Chaudhuri, A. (1999). The effects of brand attitudes and brand loyalty on brand performance. ACR European Advances.

Chi, HK, Yeh, HR, \& Yang, YT (2009). The impact of brand awareness on consumer purchase intention: The mediating effect of perceived quality and brand loyalty. The journal of international management studies, 4 (1), $135-144$

Cronin Jr, JJ, \& Taylor, SA (1992). Measuring service quality: a reexamination and extension. Journal of marketing, 56 (3), 55-68. https://doi.org/10.1177\%2F002224299205600304

de Villiers, MV, Chinomona, R., \& Chuchu, T. (2018). The influence of store environment on brand attitude, brand experience and purchase intention. South African Journal of Business Management, 49 (1), 8.

https://doi.org/10.4102/sajbm.v49i1.186

Dodds, WB, Monroe, KB, \& Grewal, D. (1991). Effects of price, brand, and store information on buyers' product evaluations. Journal of marketing research, 28 (3), 307-319. https://doi.org/10.1177\%2F002224379102800305

East, R. (1997). Consumer behavior: Advances and applications in marketing. Prentice Hall.

Erdem, T., \& Swait, J. (2004). Brand credibility, brand consideration, and choice. Journal of consumer research, 31 (1), 191-198.

Ferdinand, A. (2002). Development of extension brand buying interest. Semarang: Diponegoro University Publishing Agency.

Fishbein, M., \& Ajzen, I. (1975). Intention and Behavior: An introduction to theory and research.

Fitri, FR (2018). The influence of celebrity endorsement in Instagram social media attitude towards brand and brand image to customer purchase intention. Journal of Management and Economic Accounting, 20 (2), 7-17.

Fitzgibbon, C., \& White, L. (2005). The role of attitudinal loyalty in the development of customer relationship management is within service firms. Journal of Financial Services Marketing, 9 (3), 214-230. 
Grewal, D., Krishnan, R., Baker, J., \& Borin, N. (1998). The effect of store name, brand name and price discounts on consumers' evaluations and purchase intentions. Journal of retailing, 74 (3), 331-352. https://doi.org/10.1016/S0022-4359(99)80099-2

Gunawan, FA, \& Dharmayanti. (2014). Analysis of the Effects of Television Ads and Endorsers on Purchase Intention with Brand Awareness as Intervening Variables. Journal of Marketing Strategy, 2 (1), 1-14.

Hasanuddin, R., \& Sjahruddin, H. (2017). The structure of emotional intelligence, spiritual intelligence and its relationship with work enthusiasm and auditor performance. Structure, 3 (1).

http://dx.doi.org/10.5296/wjbm.v3i1.11321

Hellier, PK, Geursen, GM, Carr, RA, \& Rickard, JA (2003). Repurchase customer intention: A general structural equation model. European journal of marketing, 37 (11/12), 1762-1800.

https://doi.org/10.1108/03090560310495456

Hicks, JM, Page Jr., TJ, Behe, BK, Dennis, JH, \& Fernandez, RT (2005). Delighted consumers buy again. Journal of Consumer Satisfaction, Dissatisfaction and Complaining Behavior, 18, 94.

Ho, CH, Chiu, KH, Chen, H., \& Papazafeiropoulou, A. (2015). Can internet blogs be used as an effective advertising tool? The role of the blog type and brand awareness. Journal of Enterprise Information Management, 28 (3), $346-$ 362. https://doi.org/10.1108/JEIM-03-2014-0021

Hovland, CI (1959). Conflict conflicting results derived from experimental and survey studies of attitude change. American psychologist, 14 (1), 8. https://psycnet.apa.org/doi/10.1037/h0042210

Howard, JA (1994). Buyer in marketing strategy behavior. Prentice Hall.

Hoyer, WD, \& Brown, SP (1990). Effects of brand awareness on choice for common, repeat-purchase products. Journal of consumer research, 17 (2), 141-148. https://doi.org/10.1086/208544

Hutter, K., Hautz, J., Dennhardt, S., \& Füller, J. (2013). The impact of user interaction in social media on brand awareness and purchase intention: the case of MINI on Facebook. Journal of Product \& Brand Management, 22 (5/6), 342-351. https://doi.org/10.1108/JPBM-05-2013-0299

Jamali, M., \& Khan, R. (2018). The impact of consumer interaction on social media on brand awareness and purchase intention! Case study of Samsung. Journal of Marketing, 114.

Jung, NY, \& Seock, YK (2016). The impact of corporate reputation on brand attitude and purchase intention. Fashion and Textiles, 3 (1), 20.

Keller, KL (1993). Conceptualizing, measuring, and managing customer-based brand equity. Journal of marketing, 57 (1), 1-22. https://doi.org/10.1177\%2F002224299305700101

Keller, KL (1998). Branding perspectives on social marketing. ACR North American Advances.

Keller, KL (2003). Brand synthesis: The multidimensionality of brand knowledge. Journal of consumer research, 29 (4), 595-600. https://doi.org/10.1086/346254

Keller, KL (2008). Strategic branding management: Building, measuring, and managing brand equity (3rd ed.). Upper Saddle River: Prentice Hall.

Kock, N. (2010). Using WarpPLS in e-collaboration studies: An overview of five main analysis steps. International Journal of e-Collaboration (IJeC), 6 (4), 1-11. https://doi.org/10.4018/jec.2010100101

Kock, N. (2015). Common method bias in PLS-SEM: A full collinearity assessment approach. International Journal of e-Collaboration (IJeC), 11 (4), 1-10. https://doi.org/10.4018/ijec.2015100101

Kotler, P., \& Armstrong, G. (2000). 2001, Principles of Marketing. A South Asian Perspective.

Kotler, Philip. (1997). Marketing Management Analysis of Planning, Implementation and Control (translation of Jaka Wasana). Salemba Empat. Jakarta.

Lee, EB, Lee, SG, \& Yang, CG (2017). The influences of advertising attitude and brand on purchase advertising of smartphone advertising. Industrial Management \& Data Systems, 117 (6), 1011-1036. https://doi.org/10.1108/IMDS-06-2016-0229

Loudon David, L., \& Della, BAJ (1993). Consumer Behavior. McGraw USA ,.

Macdonald, EK, \& Sharp, BM (2000). Effect on brand awareness of consumer decision making for a common, repeat purchase product :: A replication. Journal of business research, 48 (1), 5-15. https://doi.org/10.1016/S0148-2963(98)00070-8 
MacKenzie, SB, \& Spreng, RA (1992). How does motivation moderate the impact of central and peripheral processing on brand attitudes and intentions? Journal of consumer research, 18 (4), 519-529. https://doi.org/10.1086/209278

Mohseni, S., Jayashree, S., Rezaei, S., Kasim, A., \& Okumus, F. (2018). Attractive tourists to websites: the structural relationship between brand websites, personal value, shopping experience, perceived risk and purchase intention. Current Issues in Tourism, 21 (6), 616-645. https://doi.org/10.1080/13683500.2016.1200539

Monga, AB, \& John, DR (2008). When does negative brand publicity hurt? The moderating influence of analytic versus holistic thinking. Journal of Consumer Psychology, 18 (4), 320-332.

https://doi.org/10.1016/i.jcps.2008.09.009

Nugraha, A., \& Setyanto, RP (2018). The Effects of Vlogger Credibility as Marketing Media on Brand Awareness to Customer Purchase Intention. Journal of research in management, 1 (2).

Pandjaitan, DH (2018). An Analysis of Influence Brand Awareness on Purchase Intention in Bandar Lampung City's Online Transportation Service (Study on Y Generation Consumers). KnE Social Sciences, 3 (10).

Parks, JC (2018). Identification of the brand lifestyle of southern lifestyle brands and their impact on perceived quality, brand attitude, and purchase intention (Doctoral dissertation, University of Alabama Libraries).

Percy, L., \& Donovan, RJ (1991). A better advertising planning grid.Journal of advertising research,31(5), 11-21.

Percy, L., \& Rossiter, JR (1992). A model of brand awareness and brand attitude advertising strategies. Psychology \& Marketing, 9 (4), 263-274. https://doi.org/10.1002/mar.4220090402

Percy, L., \& Rossiter, JR (1997). A theory-based approach to pretesting advertising. Measuring advertising effectiveness, 267-281.

Peter, JP, \& Olson, JC (2000). Consumer behavior: Consumer behavior and marketing strategies. Jakarta: Erlangga.

Peter, JP, Olson, JC, \& Grunert, KG (1999). Consumer behavior and marketing strategy (pp. 329-48). London: McGraw-Hill.

Pitta, DA, \& Prevel Katsanis, L. (1995). Understanding brand equity for successful brand extension. Journal of consumer marketing, 12 (4), 51-64. https://doi.org/10.1108/07363769510095306

Ramli, AH, \& Sjahruddin, H. (2015). Building patient loyalty in healthcare services. International Review of Management and Business Research, 4 (2), 391.

Romaniuk, J., Wight, S., \& Faulkner, M. (2017). Brand awareness: revisiting an old metric for a new world. Journal of Product \& Brand Management, 26 (5), 469-476. https://doi.org/10.1108/JPBM-06-2016-1242

Sallam, MA, \& Algammash, FA (2016). The effect of attitude toward advertising on attitude toward brand and purchase intention. International Journal of Economics, Commerce and Management, 4 (2), 509-520.

Shank, DB, \& Robinson, DT (2019). Who's responsible? Representative 'autonomy alters customers' emotion and repurchase intentions toward organizations. Journal of Consumer Marketing. https://doi.org/10.1108/JCM-062017-2226

Shapiro, S., \& Krishnan, HS (2001). Memory-based measures for assessing advertising effects: A comparison of explicit and implicit memory effects. Journal of advertising, 30 (3), 1-13.

https://doi.org/10.1080/00913367.2001.10673641

Singh, RP, \& Banerjee, N. (2018). Exploring the influence of celebrity credibility on brand attitude, advertisement attitude and purchase intention. Global Business Review, 19 (6), 1622-1639.

https://doi.org/10.1177\%2F0972150918794974

So, IG, \& Simamora, BH (2015). The influence of website quality, brand awareness and perceived quality products on purchase intention of online store video games. In 2015 the International Conference on Technology, Informatics, Management, Engineering \& Environment (TIME-E) (pp. 31-33). IEEE. https://doi.org/10.1109/TIME-E.2015.7389743

Soderlund, M., \& Ohman, N. (2003). Behavioral intentions in satisfaction research revised. Journal of Consumer Satisfaction, Dissatisfaction and Complaining Behavior, 16, 53.

Themba, OS, Razak, N., \& Sjahruddin, H. (2019). Increasing customers' loyalty. The contribution of marketing strategy, service quality and customer satisfaction. Archives of Business Research, 7 (2).

https://doi.org/10.14738/abr.72.6114.

Till, BD, \& Baack, DW (2005). Recall and persuasion: does creative advertising matter ?. Journal of Advertising, 34 (3), 47-57. https://doi.org/10.1080/00913367.2005.10639201 
Ullrich, S., \& Brunner, CB (2015). Negative online consumer reviews: effects of different responses. Journal of Product \& Brand Management, 24 (1), 66-77. https://doi.org/10.1108/JPBM-05-2014-0611

Um, NH, \& Kim, S. (2016). Determinants for effects of celebrity negative information: when to terminate a relationship with a celebrity endorser in trouble?. Psychology \& Marketing, 33 (10), 864-874.

https://doi.org/10.1002/mar.20923

Wu, SI, \& Ho, LP (2014). Perceived influence and brand awareness on the purchase intention of innovation products, for example the iPhone. International Journal of Innovation and Technology Management, 11 (04), https://doi.org/10.1142/S0219877014500266

Yu, M., Liu, F., Lee, J., \& Soutar, G. (2018). The influence of negative publicity on brand equity: attribution, image, attitude and purchase intention. Journal of Product \& Brand Management, 27 (4), 440-451. https://doi.org/10.1108/JPBM-01-2017-1396

Zeithaml, VA (1988). Consumer perceptions of price, quality and value: a means-end model and synthesis of evidence. Journal of marketing, 52 (3), 2-22. https://doi.org/10.1177\%2F002224298805200302 